Pesq. Vet. Bras. 28(1):19-22, janeiro 2008

\title{
Spontaneous poisoning by larvae of Perreyia flavipes (Pergidae) in sheep ${ }^{1}$
}

\author{
Djeison Lutier Raymundo², Pedro Soares Bezerra Junior², Paulo Mota \\ Bandarra², Pedro Miguel Ocampos Pedroso², Eduardo Conceição de \\ Oliveira $^{2}$, Caroline Argenta Pescador ${ }^{2}$ and David Driemeier ${ }^{2^{*}}$
}

\begin{abstract}
Raymundo D.L., Bezerra Junior P.S., Bandarra P.M., Pedroso P.M.O., Oliveira E.C., Pescador C.A. \& Driemeier D. 2008. Spontaneous poisoning by larvae of Perreyia flavipes (Pergidae) in sheep. Pesquisa Veterinária Brasileira 28(1):19-22. Departamento de Patologia Clínica Veterinária, Universidade Federal do Rio Grande do Sul, Avenida Bento Gonçalves 9090, Porto Alegre, RS 91540-000, Brazil. E-mail: davetpat@ufrgs.br

From a flock of 175 Texel sheep 25 animals died after consumption of a sawfly larvae subsequently identified as Perreyia flavipes. The disease occurred in June-July 2006 on a farm located in the county of Encruzilhada do Sul, Rio Grande do Sul, Brazil. Although there were 11 cattle in the same paddock, none of them was affected. High numbers of compact masses containing up to 150 larvae were scattered in the paddock where the animals were grazing. Most affected sheep showed severe apathy during 24$36 \mathrm{~h}$ before death, but weakness, muscular tremors and depression were also observed. Necropsy was performed on six sheep and the main macroscopic lesions were hemorrhages in the subcutaneous tissues, endocardium, gallbladder wall, and abomasal mucosa. In all animals was found hydrothorax, hydropericardium, ascites, and mild jaundice. Edema in the abomasal folds, mesentery, perirenal tissues, and gallbladder wall were also seen. The livers were yellowish with disseminated pinpoint hemorrhages in the parenchyma and had an enhanced lobular pattern. Perreyia flavipes larval body fragments and heads were found in the forestomach contents of the six sheep. Feces were scant, dry and formed balls coated by mucus and streaks of blood. Similar contents were also present at the end of the cecum. Prominent microscopic lesions included severe and diffuse periacinar or massive necrosis of hepatocytes associated with multifocal random hemorrhages. Diffuse necrosis of lymphoid follicles in lymph nodes and Peyer's patches, lymphoid depletion and necrosis in germinative centers of the spleen, and diffuse vacuolization in the renal tubular epithelia were also seen.
\end{abstract}

INDEX TERMS: Liver necrosis, Perreyia flavipes, sawfly larval poisoning, sheep.

RESUMO.- [Intoxicação espontânea por larvas de Perreyia flavipes (Pergidae) em ovinos.] Vinte e cinco ovinos Texel de um rebanho de 175 morreram após ingerirem larvas posteriormente identificadas como Perreyia flavipes. A doença ocorreu em Junho e Julho de 2006, em uma propriedade localizada em Encruzilhada do Sul,

\footnotetext{
${ }^{1}$ Received on September 4, 2007.

Accepted for publication on September 20, 2007.

2 Departamento de Patologia Clínica Veterinária, Universidade Federal do Rio Grande do Sul (UFRGS), Av. Bento Gonçalves 9090, Porto Alegre, RS 91540-000, Brazil. *Corresponding author: davetpat@ufrgs.br
}

Rio Grande do Sul. Embora houvesse também 11 bovinos no mesmo potreiro, nenhum foi afetado. Grandes quantidades de massas compactas, contendo cada uma mais de 150 larvas, estavam espalhadas na pastagem onde os animais pastoreavam. Os ovinos afetados apresentavam apatia severa por 24 a 36 horas antes da morte. Fraqueza, tremores musculares e depressão também foram vistos. Em necropsias realizadas em seis animais, as principais alterações macroscópicas foram hemorragias no tecido subcutâneo, endocárdio, parede da vesícula biliar e mucosa abomasal. Hidrotórax, hidropericárdio, ascite e icterícia estavam presentes em todos os animais. 
Edema nas pregas do abomaso, mesentério, tecidos perirenais e parede da vesícula biliar também foram observados. Os fígados estavam amarelados, com petéquias disseminadas no parênquima e padrão lobular aumentado. Fragmentos de corpos e cabeças de larvas de Perreyia flavipes foram encontrados nos conteúdos ruminais dos seis animais. O conteúdo da porção final do cólon, ceco e reto estava seco, com muco aderido e estrias de sangue. Necrose de hepatócitos periacinar ou massiva associada com hemorragias multifocais aleatórias foi o principal achado histológico, mas também havia necrose difusa em folículos linfóides nas placas de Peyer e linfonodos, depleção linfóide e necrose em centros germinativos no baço e vacuolização no epitélio tubular renal.

TERMOS DE INDEXAÇÃO: Intoxicação, larvas, necrose hepática, ovinos, Perreyia flavipes.

\section{INTRODUCTION}

Worldwide outbreaks of acute hepatic necrosis in livestock have been attributed to the ingestion of larvae from insects of the suborder Symphyta (sawfly), Hymenoptera (Dadswell et al. 1985, Thamsborg et al. 1987, Smith 1990, Dutra et al. 1997). D-amino acid-containing peptides have been found to be responsible for sawfly larval poisoning (Kannan et al. 1988, Oelrichs et al. 1999). The palatability of sawfly larvae and nutritional deficiencies have indicated as predisponent factors (McKenzie et al. 1985, Dutra 1997).

Larvae of Lophyrotoma interrupta (Pergidae), Arge pullata (Argidae), Perreyia lepida (Pergidae), and Perreyia flavipes (Pergidae) have been associated with spontaneous poisoning and deaths of cattle and sheep in Australia (Dadswell et al. 1985, McKenzie et al. 1985), sheep and goats in Denmark (Thamsborg et al. 1987), pigs in Brazil (Camargo 1955), and cattle and sheep in Uruguay (Dutra 1997, Dutra et al. 1997), respectivelly. Experimental intoxication has been induced in pigs (Soares et al. 2001), cattle, and sheep (Dutra 1997). This communication reports an outbreak of natural poisoning by the sawfly larvae $P$. flavipes in sheep in Brazil.

\section{MATERIALS AND METHODS}

Clinical and epidemiological data were retrieved from the staff and owner of the establishment where the outbreak occurred. Six Texel sheep were necropsied and samples of liver, kidney, spleen, heart, lungs, lymph nodes, brain, intestines, and gastric compartiments were collected from four animals, fixed in buffered formalin $10 \%$, routinely processed for histology and stained by hematoxylin and eosin (Allen 1992).

\section{RESULTS}

The disease occurred in June-July 2006 on a farm located in the county of Encruzilhada do Sul, Rio Grande do Sul, Brazil. The flock comprised 175 Texel sheep that were kept on 40 hectares of native pastures and were in good nutritional status. In total, 25 animals died. Although there were 11 cattle in the same paddock, none of them was affected. High numbers of compact masses of a sawfly larvae subsequently identified as Perreyia flavipes (Smith 1990) were scattered on the paddock in which animals were grazing. Each group contained up 150 larvae which were about $2.5 \mathrm{~cm}$ long and black in color (Fig.1). Most affected sheep showed severe apathy that lasted approximatelly 24-36 $\mathrm{h}$ before death, but weakness, muscular tremors, and depression were also observed in some animals.

The main macroscopic lesions were hemorrhages in the subcutaneous tissues, endocardium, gallbladder wall, and abomasal mucosae. All animals presented hydrothorax, hydropericardium, ascites, and mild jaundice. There was also edema in the abomasal folds, mesentery, perirenal tissues, and gallbladder wall. The livers had a yellowish coloration with disseminated pinpoint hemorrhages in parenchyma (Fig.2) and enhanced lobular pattern at the cut surface (Fig.3). P. flavipes larval body fragments and heads were found in the forestomach contents of the

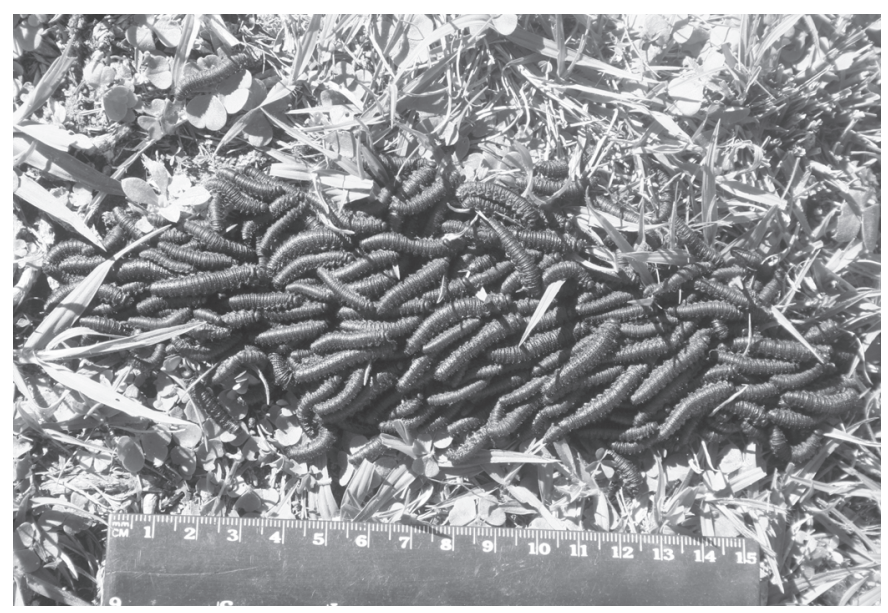

Fig.1. Compact mass of Perreyia flavipes Know, 1899 (Hymenoptera: Pergidae) larvae crawling on the ground. EncruziIhada do Sul, Rio Grande do Sul, Brazil, June 2006.

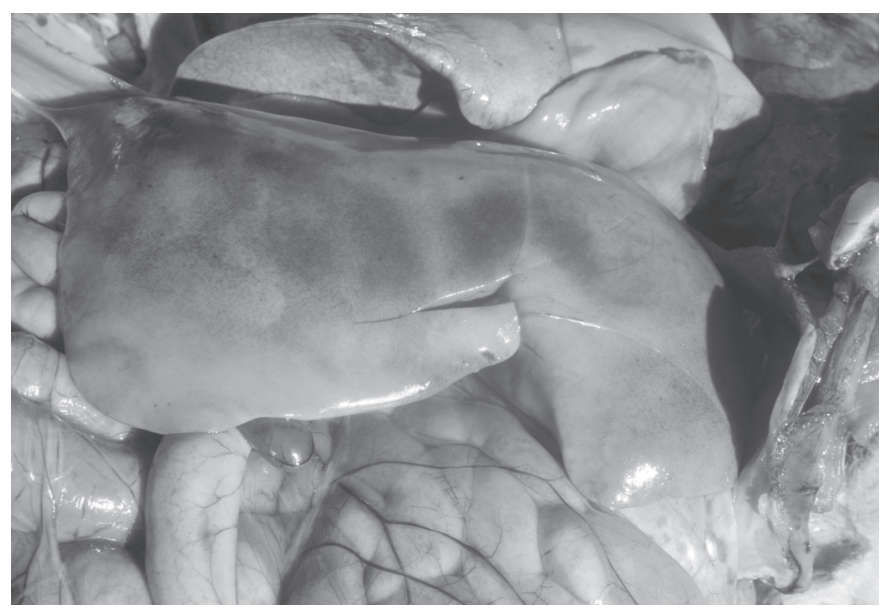

Fig.2. Liver with yellowish coloration and disseminated pinpoint hemorrhages in the Perreyia flavipes poisoning of sheep. 


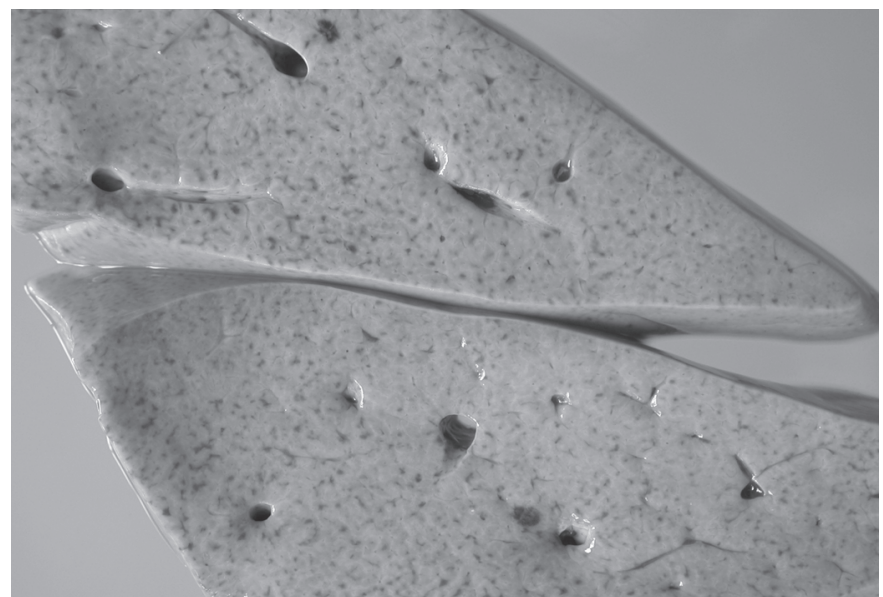

Fig.3. Yellowish coloration with disseminated pinpoint hemorrhages in parenchyma and enhanced lobular pattern of the liver cut surface, in Perreyia flavipes poisoning of the sheep.



Fig.4. Perreyia flavipes larval body fragments and heads were found in the forestomach contents of the six sheep poisoned by the insect and on which post-mortem examination was performed.

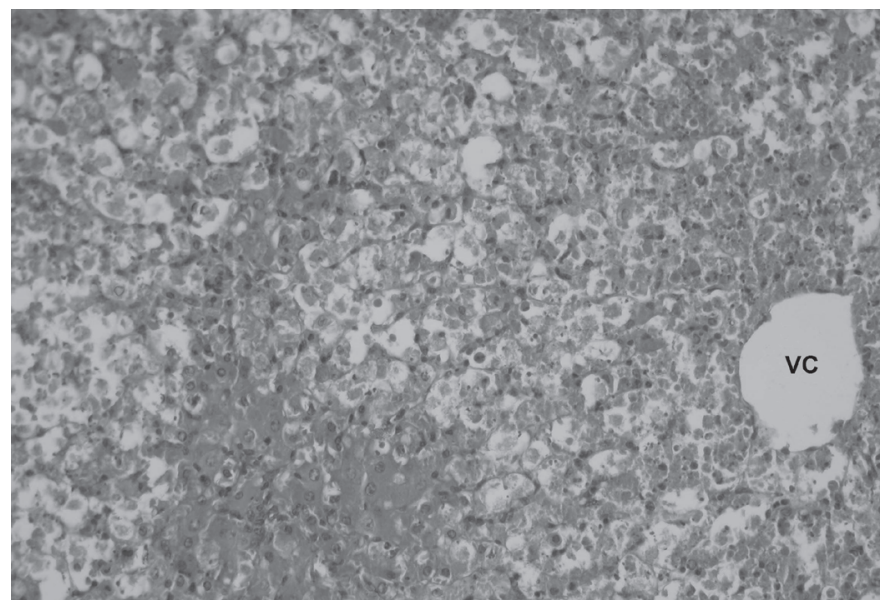

Fig.5. Severe and massive centrolobular necrosis of the liver in the Perreyia flavipes poisoning of sheep. Centrolobular vein (VC). HE, obj.20x. six sheep (Fig.4). Feces were scant, dry and formed balls coated by mucus and streaks of blood. Similar contents were also present at the end of the cecum.

Prominent microscopic lesions included severe and diffuse periacinar or massive necrosis of hepatocytes (Fig.5) associated with multifocal random hemorrhages. Necrotic hepatocytes had vacuolizated cytoplasm and nuclei, which also were picnotic and had condensed cromatin or cariolysis. Lymph nodes and Peyer's patches showed diffuse necrosis of lymphoid follicles. In three sheep, the spleens had lymphoid depletion and diffuse necrosis of the germinative centers (lymphocytes with picnotic nuclei and condensed cromatin). Renal tubular epithelial cells had diffuse vacuolization.

\section{DISCUSSION}

Clinical signs and necropsy findings were consistent with a number of acute hepatoxicosis in sheep such as the diseases caused by the consumption of the algae Microcystis aeruginosa (Jackson et al. 1984) and the plants Sessea brasiliensis (Chaulet et al. 1990), Vernonia mollissima (Döbereiner et al. 1976, Gava et al. 1987), Wedelia glauca (Collazo \& Riet-Correa 1996), and Xanthium cavanillessi (Loretti et al. 1999).

Body cavity fluid collections, edema of certain organs, scattered hemorrhages, and characteristic dry feces have all been common necropsy findings in the ovine acute hepatotoxicosis caused by Sessea brasiliensis (Chaulet et al. 1990), Xanthium cavanillessi (Loretti et al. 1999), Vernonia mollissima (Gava et al. 1987), Wedelia glauca (Collazo and Riet-Correa 1996), and Microcystis aeruginosa (Jackson et al. 1984).

On the other hand, necrosis in lymphoid tissues may help to differentiate sawfly larvae poisoning from other acute hepatotoxicosis (McKenzie et al. 1985). Lymphoid depletion and necrosis of the germinative centers have also been seen in the toxicosis caused by Polygala klotzschii, Baccharis coridifolia, B. megapotamica var. megapotamica, B. megapotamica var. weirii, Ricinus communis, and Schultesia guianensis (Tokarnia et al. 2000), but not in cases in which acute hepatic necrosis occurs.

Outbreaks of sudden death of livestock have been linked to the ingestion of larvae from Symphyta suborder of Hymenoptera in several countries (McKenzie et al. 1985, Thamsborg et al. 1987, Dutra et al. 1997, Soares et al. 2001). The absence of known hepatotoxic plants in the area, the great amounts of Perreyia flavipes larvae on the pastures in which animals were grazing, and the presence of the larval fragments in the ruminal contents of dead sheep were strong evidence supporting the diagnosis of sawfly (Perreyia flavipes) larval poisoning, which was also based on the hepatic and lymphoid pathological findings.

Contrary to previous report (Dutra et al. 1997), sheep on this pasture appeared to be more susceptible than cattle. Different levels of larvae on the pastures could explain why many animals were not affected (Dadswell et 
al. 1985). However, since similar doses have been reported as toxic for both species (Thamsborg et al. 1987, Dutra 1997), cattle should ingest higher quantity of larvae than sheep. Since $P$. flavipes larvae may present high palatability (McKenzie et al. 1985, Dutra 1997), it is also posssible that sheep were preferably affected because of their higher selective grazing behaviour, compared with cattle. The season in which the outbreak occurred is consistent with available data on the insect biology (Dutra et al. 1997). The daily collection of larvae masses from the pastures prevented further losses.

Acknowledgements.- The authors are grateful to Dr. Fernando Zanotta da Cruz from the Department of Entomology, UFRGS, for the identification of the insect.

\section{REFERENCES}

Allen T.C. 1992. Hematoxylin and eosin, p.53-58. In: Prophet E.B., Mills B., Arrington J.B. \& Sobin L.H. (ed.), Laboratory Methods in Histotechnology. American Registry of Pathology, Washington, DC.

Camargo O.R. 1955. Contribuição ao estudo do Tenthredinideo Mata Porcos, Paraperreyia dorsuaria (Know, 1899), no Rio Grande do Sul. Thesis, Universidade Federal do Rio Grande do Sul, Porto Alegre.

Chaulet J.H.F., Peixoto P.V. \& Tokarnia C.H., 1990. Intoxicação experimental por Sessea brasiliensis (Solanaceae) em bovinos, ovinos e caprinos. Pesq. Vet. Bras. 10(3/4):71-74.

Collazo L. \& Riet-Correa F. 1996. Experimental intoxication of sheep and cattle with Wedelia glauca. Vet. Hum. Toxicol. 38(3):200-203.

Dadswell L.P., Abott W.D. \& McKenzie R.A. 1985. The occurrence, cost and control of sawfly larval (Lophyrotoma interrupta) poisoning of cattle in Queensland 1972-81. Aust. Vet. J. 62(3):94-97.

Döbereiner J., Tokarnia C.H. \& Purisco E. 1976. Vernonia mollissima, planta tóxica responsável por mortandades em bovinos no sul de Mato Grosso. Pesq. Agropec. Bras., Sér. Vet. 11:49-58.
Dutra F. 1997. Intoxicação por larvas de Perreyia flavipes. Caracterização da doença e biologia do inseto. Dissertation, Universidade Federal de Pelotas, RS.

Dutra F., Riet-Correa F., Mendez M.C. \& Paiva N. 1997. Poisoning of cattle and sheep in Uruguay by sawfly (Perreyia flavipes) larvae. Vet. Hum. Toxicol. 39(5):281-286.

Gava A., Peixoto P.V. \& Tokarnia C.H. 1987. Intoxicação experimental por Vernonia mollissima em ovinos e bovinos. Pesq. Vet. Bras. 7(2):3341

Jackson A.R.B., McInnes A., Falconer I.R. \& Runnegar M.T. 1984. Clinical and pathological changes in sheep experimentally poisoned by the blue-green alga Microcystis aeruginosa. Vet. Pathol. 21(1):102-113.

Kannan R., Oelrichs P.B., Thamsborg S.T. \& Willians D.H. 1988. Identification of the octapeptide lophyrotomin in the European birch sawfly (Arge pullata). Toxicon 26(2):224-226.

Loretti A.P., Bezerra P.S., Ilha M.R.S., Barros S.S. \& Barros C.S.L. 1999. Intoxicação experimental pelos frutos de Xanthium cavanillesii (Asteraceae) em ovinos. Pesq. Vet. Bras. 19(2):71-78.

McKenzie R.A., Rogers R.J. \& Oelrichs P.B. 1985. Sawfly larvae poisoning of cattle in Queensland, p.524-532. In: Proceedings of the Australia-U.S.A. Poisonous Plants Symposium, Brisbane.

Oelrichs P.B., Macleod J.K., Seawright A.A., Moore M.R., NG J.C., Dutra F., Riet-Correa F., Mendez M.C. \& Thamsborg S.M. 1999. Unique toxic peptides isolated from sawfly larvae in three continents. Toxicon 37(3):537-544.

Smith D.R. 1990. A synopsis of the sawflies (Hymenoptera, Symphyta) of America South of the United States: Pergidae. Revta Bras. Entomol. 34:7-200.

Soares M.P., Riet-Correa F., Smith D.R., Pereira Soares M., Mendez M.C. \& Brandolt A.L. 2001. Experimental intoxication by larvae of Perreyia flavipes Know, 1899 (Hymenoptera: Pergidae) in pigs and some aspects on its biology. Toxicon 39(5):669-678.

Thamsborg S.M., Jorgensen R.J. \& Brummerstedt E. 1987. Sawfly poisoning in sheep and goats. Vet. Rec. 121(11):253-255.

Tokarnia C.H., Döbereiner J. \& Peixoto P.V. 2000. Plantas Tóxicas do Brasil. Editora Helianthus, Rio de Janeiro. 